\title{
Teaching Mode Reform for Ideological and Political Courses in Colleges and Universities in the Information Age
}

\author{
Jin Tan \\ School of Chemistry and Environmental Engineering, Yancheng Teachers University \\ No. 2, Hope Avenue South Road, Jangsu 224007, China
}

\begin{abstract}
After China entered the information age, a series of educational reforms were carried out, especially with the many shortcomings of modern ideological and political education, and the reform of ideological and political education with the requirements of the new era has become the focus of the country. Education reform requires content. At present, various new teaching methods have impacted the traditional methods of education. In the process of facing the opportunities and challenges brought by this period, changing the teaching mode, teaching methods and teaching concepts has become the exploration of the new period of ideological and political courses in colleges and universities. It is particularly important to focus on the fact that a variety of information in the information age has a profound impact on the psychological status of students and the shaping of the three outlooks.
\end{abstract}

Keywords: Ideological and political course; College education; Information technology

DOI: $10.7176 / \mathrm{JEP} / 11-11-06$

Publication date: April $30^{\text {th }} 2020$

\section{Introduction}

Colleges and universities are important bases for the cultivation of higher talents in China. However, for talents, it is not only necessary to make demands on knowledge, but also to pay attention to the ideological and moral education of talents. This is also because the original amount of social information is too large and students cannot make Correct judgment. In addition, as far as the situation of college students in the series of Hong Kong independence incidents in China is concerned, it is extremely important to strengthen the ideological and political education in colleges and universities, from the improvement of quantity to the improvement of quality, especially to pay attention to the cognition of students' rebellious psychology. We will strengthen the affinity of ideological and political education as much as possible, and promote further construction in meeting the psychological needs of college students in the new era and relevant guidelines.

2. The application of modern information technology in the background of ideological and political education in colleges and universities

Applying modern information education methods to education is a relatively common method at present, but in practice, this method has important and far-reaching significance. From the perspective of college students, the ideological and political teaching in traditional education adopts knowledge. Indoctrinated teaching methods, and there are insufficient conditions in teaching interaction, and this teaching method continues to be applied to college students in the new era, which will even cause college students' rebellious psychology. This phenomenon is mainly due to the colorful information technology brought by the information age, which is more attractive than the boring knowledge infusion, which naturally requires the application of information technology in the ideological and political curriculum, especially At present, information technology network education has become an important learning method for more than $96 \%$ of college graduates. The students who have grown up in this environment have been deeply influenced by information technology, so innovation and flexibility and processing of a large amount of information have become theirs. The characteristics, which also lead to the traditional knowledge instilling has been difficult to meet the requirements of contemporary college students. Therefore, in the ideological and political course, with the advent of the information age, it has gradually moved toward the reform of educational models such as multimedia information technology and online education platform. However, due to the short reform period and lack of accumulated experience, it is also There have been many cases of inadequate reform ${ }^{[1]}$.

3. The application of modern information technology in the ideological and political education in colleges and universities

3.1 From instilling education to PPT education

Inculcation education is the most common educational method in traditional education, and it is resisted by students because of its lack of scientific rationality in the teaching process. However, after the application of information technology, PPT multimedia teaching is transformed into a new era of indoctrinating education. This means that some teachers have turned indoctrinated education into a teaching method of practicing PPT. Although the teaching efficiency and the degree of understanding of students have improved, it does not meet the psychological 
expectations and teaching requirements of college students. And in terms of the actual teaching purpose of the ideological and political course, it should be based on the compression of teaching time by PPT multimedia technology and the role of the classroom main body of the college students, that is, adding the interaction between students and teachers or teaching exploration activities as much as possible. Let college students actually participate in the curriculum construction, but in the current application of electronic information technology, the latter is obviously not reflected, even compared to indoctrinating teaching, the interaction between students and teachers is even more lacking. That is to say, it has weakened the main role of students in the teaching process.

\subsection{Not using the fragmented teaching brought about by information technology}

Another major advantage brought by information technology in the new era in the field of education is fragmented teaching, which is to make full use of the free time of college students and to supplement the deficiencies in ideological and political education. As far as the time limit is concerned, it is extremely advantageous for college students who have almost a smart phone to receive and learn the teaching content through the Internet in time. However, most of the ideological and political education has not expanded on this. The teaching is still reflected in the classroom and in writing, there is no relevant online teaching content, or only the PPT reporting activities and Internet teaching are formally carried out. The emergence of this situation is firstly the lack of teachers' teaching ideas, and secondly with the teachers themselves. Related literacy related ${ }^{[2]}$.

\subsection{Grasping the key points of teaching and applying a variety of teaching methods}

The main role of the new teaching methods used in the information age is to enhance students' interest in learning, which is achieved by attracting students' attention. However, if not well planned, it may lead to the overall shift of students' attention. When the case is cited in the classroom teaching process, the student's attention to the case may be high, which may affect the effective development of the teaching content. For example, in the analysis of Western ideas, a large number of Western film fragments, such as "Transformers", "X-Men" and other eyecatching content, although may lead to increased student interest, but it is possible The student's attention was severely offset, which hindered the teacher's subsequent teaching plan and delayed the teaching plan.

\section{Specific measures for the reform of ideological and political courses in colleges and universities 4.1 Learning from changes under the five major concepts}

The five concepts are put forward by the 18th National Congress of the Communist Party of China, the most important of which is the concept of innovation, while others have grasped five aspects of China's development, and these five concepts have also provided important developments in the informationization of ideological and political courses. Direction, but it is necessary to pay attention to the thorough transformation and renewal of the teacher's ideas, in order to carry out an effective overall construction with the Internet. Therefore, compared with the five concepts applied to it, the term "implantation" seems to be more reasonable and effective, which requires the comprehensive ideological training and promotion of the university ideological and political education teachers, and better changes the teachers' Thinking work learning methods, especially for micro-classrooms and mobile teaching APPs for online education, in addition to understanding the many advantages brought by information-based teaching, especially the advantages of information-based education in time and space. As far as the current changes in international education are concerned, the subversive reform of informatization education is inevitable, and in response to President Xi Jinping's proposal in 2015 to promote educational innovation through the application of information technology development, each person will be in each time period. Every place can learn the concept of learning society and carry out it in depth, and this is also the reality that the program of expanding human intelligence proposed by inventors in the last century has become a reality[3].

\subsection{Comprehensive construction of network ideological and political courses}

The multi-faceted mix is an important part of the comprehensive construction of the network ideological and political course. This is the combination of online and offline teaching, the combination of written homework and network work, and the combination of theoretical teaching and testing teaching. In online and offline teaching, the network cloud class teaching led by the rain class is already more common. Its application has changed many shortcomings in the past teaching. For example, due to the arrangement of the seats, the students in the back row cannot clearly see the teacher's explanation. In the case of the cloud class class APP, the PPT can be uploaded in real time to help the students to understand in depth, and after teaching for a period of time, the teaching content can be detected at any time through the online class. In addition, in terms of teaching resources, teachers can also push various resources at any time, which is also a feeling of prohibiting mobile phones from entering the classroom, and comparing mobile phones as a classroom application. The important link is another method. In particular, this method can speed up the teaching rhythm and make full use of mobile phones for students' rapid detection to ensure students' classroom attendance and attention. The network operation and written teaching also avoid the appearance of forgetting the words due to over-emphasis on the network application. Students can make 
a written summary through the richness of the network resources to improve the students' literacy through various $\operatorname{aspects}^{[4]}$.

4.3 Evaluation mechanism and knowledge-rich optimization

After using the information Internet technology, it has also played an important role in teaching evaluation and knowledge development. The former is to better evaluate the students' ordinary learning through the Internet education platform, so that the learning results of the course are more through ordinary times. The composition of the learning process reduces the high scores created by the students' temporary enthusiasm. Such a scoring mechanism is more reasonable than the traditional teaching in the past, and it is a test of the hardship of the student's learning and diagnosis period. In terms of the optimization of knowledge distribution, teachers can share all the knowledge content through the Internet. In the teaching process, the teaching time is shortened through Internet information technology, and the teaching content is enriched as much as possible, which makes a lot of time. Students can be left to conduct independent discussions. During this time, teachers can organize and guide teaching activities and teaching games. Students can also conduct research on scientific research or investigation of certain social phenomena. Deepen students' understanding ability, and this process can effectively improve students' interest in ideological and political courses, and also has important significance in the enhancement of learning efficiency ${ }^{[5]}$.

\section{Conclusion}

The reform and change of ideological and political education in universities must be transformed with the advent of the information age. Especially for the specific situations of the international and China, although China has carried out the emphasis of quality education for many years, due to time experience, etc. For many reasons, there are still insufficient situations in ideological and political education, which leads to loopholes in the ideological and political education of college students, which may be exploited by lawless elements or cannot correctly understand the current international situation. Therefore, first of all, through the Internet information technology to strengthen students' interest in ideological and political courses, and then comprehensively change the teaching methods and assessment system, etc., is the primary goal of the reform of the ideological and political education information technology under the university, and after this goal is achieved, Then we should further enrich and discuss the content of the current network environment and changes in the international community.

\section{Acknowledgment}

The research is supported by Yancheng Teachers College Education and Teaching Reform Project Funding (2018YCTUJGY074).

\section{References}

[1] Yu C L, Wang J J. Analysis on the teaching evaluation of ideological and political courses in colleges and universities in the age of big data. Journal of hebei national teachers college, 2019, 39 (01): 92-98.

[2] Zhao Q S. The alienation of modern information technology and the deep integration of college ideological and political courses and its transcendence. Academic forum, 2018, 41(05): 162-167.

[3] Gao Q. New in the future: to promote the integration of ideological and political education and modern information technology innovation in the new era. Southern journal, 2018 (09): 98-102.

[4] Zhao J, Gao S J. The coupling and approach of the deep integration of ideological and political courses and mobile information technology in colleges and universities. Academic exploration, 2018(05): 146-151.

[5] Gao Q, Zhou X J, Han W B. Some important relations in the informational teaching of ideological and political theory courses in colleges and universities. Ideological and theoretical education guide, 2018(02):112-116. 